\title{
How Will Russia's Future CEOs Manage? A Survey of Attitudes toward Loyalty, Leadership and Teamwork ${ }^{*}$
}

\author{
Igor Gurkov/Shlomo Maital ${ }^{* *}$
}

This paper reports on the first large-sample survey of management attitudes among over 1,400 Russian mid-level managers and 740 Chief Executive Officers (CEOs). We find that while CEOs focus on knowledge of finances, company operations and legislation, as ideal CEO's qualities, mid-level managers stress conflict resolution and team-building skills. The new generation of Russian managers, we surmise, may be less autocratic and hierarchical, and more teamoriented, than their predecessors. Western firms should seek to establish limited joint ventures with Russian firms, where talented young managers can reveal and test their management skills.

In dieser Arbeit wird die erste groß angelegte Umfrage zum Thema Grundhaltungen der Unternehmensführung vorgestellt. Für diese Untersuchung wurden über 1400 russische Manager der mittleren Ebene und 740 Geschäftsführer befragt. Es wurde herausgefunden, dass Geschäftsführer andere Vorstellungen davon haben, welche Eigenschaften einen Manager auszeichnen sollen, als die Manager der mittleren Ebene. Erstere schätzen Eigenschaften wie Fachwissen in Finanzen, Unternehmensführung und Recht, während zweitere größere Betonung auf Konfliktlösefertigkeiten und Teamfähigkeit legen. Wir vermuten, dass die neue Managergeneration, die in Russland heranwächst, weniger autokratische und hierarchische Züge aufweist und stärker teamorientiert ist, als ihre Vorgänger. Westliche Unternehmen sollten versuchen, Joint Ventures mit russischen Unternehmen einzugehen, in denen talentierte junge Manager ihre Fertigkeiten entdecken und testen können.

* manuscript received: 19.09.2000, revised: 12.10.2000, accepted: 27.10.2000;

** Igor Gurkov, born 1965, Professor and Head of the Labopratory for Organizational Development at the State University - Higher School of Economics, Moscow. Major areas of interest: Organizational Change and Development, Management of Innovations, Human Resource Management.

Shlomo Maital, born 1942, Professor, Davidson Faculty of Industrial Engineering and Management, Technion - Israel Institute of Technology; and Academic Director, Technion Institute of Management, Haifa, Israel. Major areas of interest: Managerial Economics, Economic and Organizational Psychology, Technometrics, Entrepreneurship and Management of Innovations. 


\section{Introduction}

Scarcely a decade after Russia launched a remarkable transition from socialist planning to capitalist free markets, a new transition has begun -- the shift from an old generation of managers, many of them engineers, who rose from the ranks of workers to run state-owned and privatized enterprises, to a new generation of managers, whose managerial experience is largely post-Glasnost and whose attitudes and approach to management are very different. This transition occurs at a time of crisis and instability in the Russian economy, after a massive devaluation of the rouble and debt default in August 1998. ${ }^{1}$ For Western managers and investors interested in doing business in Russia, and with Russians, this generational transition is a matter of great importance - for Russia's current mid-level managers will within a decade take the reins of thousands of Russian firms, and in fact are already doing so. As many multinationals consider now not only how to re-capture Russian markets "from within," but also how to use Russia as a manufacturing base for other markets, the understanding of how this new generation of managers thinks and behaves is of great importance.

Since 1990, much has been said and written about the transformation of Russian management (Czinkota, 1997; Elenkov, 1997; Gurkov and Maital, 1996; Gurkov, 1997; Lawrence and Vlachoutsicos, 1990; May, Young and Ledgerwood, 1998; Puffer, 1996; Shekshnia, 1994, 1998). Unfortunately, as was stressed by Fey and Denison (1998, p. 2), "the research that has been conducted has primarily been based on anecdotal evidence or small-sample studies." Moreover, most of the attention has been devoted to the management in joint ventures or subsidiaries of Western multinationals. Meanwhile, the locallycontrolled privatised companies form the backbone of the Russian economy, and more than 13,000 state-owned companies continue to play an important role in various market segments.

We therefore decided to conduct a large-scale sample survey, to address the following research questions:

1) How coherent are Russian industrial companies, in terms of the attitudes and perceptions of CEOs in contrast with mid-level managers?

1 There are signs that again, the Russian phoenix is rising from the ashes of economic disaster, for the n-th time. Russia has demonstrated again the incredible ability to cope with perilous economic situations. Just two years after the financial collapse, Russian industrialists whisper: "Boom." The fourfold fall of the local currency against the American dollar and the raise of oil prices made Russian exports highly competitive, and revitalised many domestic industries. In August 2000, industrial production was 11 per cent higher than a year ago, trade surplus reached US\$ 51.1 billion (Economist, October, 2000, p. 156) 
2) How do middle managers differ from their bosses in leadership patterns and preferences?

3) Will middle managers serve as effective change agents for introduction of new business methods, organisational forms and ownership structures in their companies?

4) How can Western companies discover leadership potential among young Russian managers?

\section{The research instruments}

The main research instrument were two questionnaires - one of CEOs and another for middle managers which consisted of several blocks accordingly to the goals of the study.

In their questionnaire, CEOs were asked to indicate four groups of management qualities:

- Qualities that reflect their personal leadership styles.

- Qualities which are perceived as missing in their personal leadership styles.

- Qualities which are believed to be necessary for middle managers.

- Qualities their middle managers are missing much.

CEOs were asked to mark an unspecified number of qualities on the list of 14 qualities with a possibility to add additional items. The list of possible "ideal qualities" was inspired by the work of Kouzes and Posner (1995), who studies the images of "the most admired leaders."

In a special questionnaire for middle managers, the middle managers were asked to indicate five groups of management qualities:

- Qualities which reflect the leadership style of the most effective CEOs.

- Qualities which are perceived as missing by the Chief Executive Officer of their own company.

- Qualities which reflect their personal leadership style

- Qualities which are perceived as missing in their personal management styles.

- Qualities which are perceived as missing in their ultimate subordinates.

Middle managers were offered the same 14-item scale as for CEOs for the first four sets of questions and a slightly shorter scale (12 items) to assess the missing qualities of their ultimate subordinates. 
In addition, both CEOs and middle managers were to indicate their attitudes towards possible changes in their companies and around, including the change of ownership, the change of top management, the change of organizational structure, the possible nationalization of the company etc. We used here the following two-pole scale: "-2" = "possible highly negative outcomes," $0=$ "influence," +2 = "highly positive outcomes."

Middle managers should indicate their agreement with five statements as "I am absolutely sure in security of my job in the near future," "I would not move to another company even for a higher salary" etc. For these questions we used a 5point scale, ranged from "1"- "completely disagree" to "5" - "completely agree." Finally, for both CEOs and middle managers we inserted into the questionnaires questions about the main line of business, the size of the company (in terms of sales volume and personnel number), the location, and the ownership status of the company ${ }^{2}$.

\section{The Sample}

In October-December 1998, at the midst of the financial collapse, we conducted the survey, which embraced 742 CEOs and 1402 senior and middle-level managers of Russian companies. Each respondent came from a different company. The respondents presented companies of all legal forms in main Russian industries, which were situated in 78 Russian regions.

The questionnaires were administered through the network of the Federal Commission of Preparation of Management Cadres. This Commission administers the President's Management Re-training programme. That five-year programme aims to re-train 5,000 managers per year and to create a pool of "would-be-leaders" for main Russian industries. The programme comprises short theoretical courses in local universities and business schools with placement of managers as "secondees" in European or American companies. The Commission has local officers in all Russian regions. Therefore, for middle managers the questionnaires were distributed and collected in classes during the local theoretical training, while for CEOs questionnaires were distributed and collected by program's officers during various meetings in local administrations. That gave us a very high response rate - more than 90 per cent for middle managers and more than 80 per cent for CEOs.

Around two thirds of CEOs were older than 40 years. Almost 18 per cent of the surveyed CEOs represented state-owned companies and 47.6 per cent of the

2 The complete questionnaire is available from the Laboratory of Organisational Development, State University - Higher School of Economics, Russia, 125319, Moscow, Kochnovski proezd, 3., e-mail: hsestud@online.ru 
CEOs came from privatized companies. For a detailed description of the sample see (Gurkov, 1998; 1999).

All of the surveyed middle managers were under the age of 40, and 52.7 per cent of the surveyed trainees were younger than 30 . Regarding the ownership status of their companies, 15.4 per cent of the surveyed trainees came from stateowned companies, 39.8 per cent from privatised companies, and the rest from private companies, established after 1992.

For CEOs, our sample is quite representative for the "overall population" of Russian industrial leaders. For middle managers, there is a systemic shift towards younger managers. However, for the purpose of the study of crossgenerational differences, this shift is quite useful.

\section{Profile of the "Ideal” Boss}

The first step was to determine the leadership preferences of actual company heads and young "would-be-leaders." We asked both CEOs and young managers to state the qualities of a CEO that are vital during the hyper-turbulent times. Based on the answers, we identified four groups of abilities perceived to be necessary to run a Russian industrial company (see Table 1).

- sound knowledge of "financial machinery": 70 per cent of CEOs and 60 per cent of middle managers stressed that ability as absolutely necessary.

- team-building skills: 67 per cent of CEOs and 80 per cent of middle managers.

- quick decision-making: 67 per cent of CEOs and 77 per cent of middle managers.

- ability to establish business contacts: 59 per cent of CEOs and 71 per cent of middle managers

There is considerable coherence in the attitudes of the two groups. The rank order of six of the 13 items were identical, and for the seven items that differed in rank order of importance, only for one item was that difference as large as four ("knowledge of finances", ranked \#1 by CEOs, but only \#5 by mid-level managers).

However, closer study of the data shows that the configuration of desired qualities differs. The current CEOs view the "ideal CEO" as a dynamic financier with the solid erudition in business legislation and in-depth knowledge of company operations. Future CEOs put strong emphasis on leadership abilities of the CEO. More than 80 per cent of younger managers stressed "team-building skills" as necessary to run a company during the crisis times. Younger managers also see much clearly the scrupulous work required to build a coherent management team: a third of "would-be leaders" selected such qualities as 
"ability of accurate performance assessment," "propensity to conflict prevention" and "willingness for mentoring" as organic characteristics of a successful CEO. Good interpersonal skills of the CEO have also to be proved "outside the factory walls" - in establishing productive business contacts. At the same time, accordingly to younger managers, the successful CEOs do not need to have the outstanding expertise in company operations or sound knowledge of business law - they should rely in these areas on qualified subordinates. (See Figure 1).

Table 1. Qualities of an Ideal CEO according to Russian CEOs and Young Managers (percentages)

\begin{tabular}{|l|c|c|}
\hline \multicolumn{1}{|c|}{ Quality } & CEO & Young Managers \\
\hline Knowledge of finances & 70,1 & 59,6 \\
\hline Quick decision-making & 67,2 & 77,7 \\
\hline Team-building skills & 67,5 & 80,4 \\
\hline Quick assessment of the situation & 63,3 & 77,5 \\
\hline $\begin{array}{l}\text { Ability to establish contacts outside the } \\
\text { company }\end{array}$ & 58,9 & 71,9 \\
\hline Ability to bear responsibility & 55,8 & 59,0 \\
\hline $\begin{array}{l}\text { In-depth knowledge of company } \\
\text { operations }\end{array}$ & 47,4 & 37,8 \\
\hline Knowledge of business legislation & 41,2 & 33,7 \\
\hline Ability to predict conflicts & 26,8 & 35,7 \\
\hline $\begin{array}{l}\text { Ability to assess the performance of } \\
\text { subordinates accurately }\end{array}$ & 23,5 & 37,4 \\
\hline Ability to resolve conflicts & 18,1 & 29,2 \\
\hline Tact & 16,9 & 27,7 \\
\hline $\begin{array}{l}\text { Willingness to transfer his/her } \\
\text { knowledge }\end{array}$ & 12,2 & 16,9 \\
\hline
\end{tabular}

Summing up Table 1 and Figure 1: current Russian CEOs believe in an autocratic leadership style, where the firm is led by someone who has wide 
knowledge to make key decisions. Future CEOs believe in a consensual leadership style, where the CEO is more a conductor of an orchestra than the captain of a ship. Future Russian CEOs seem much closer to their American counterparts in preferred management style than current CEOs.

\section{Figure 1. Ideal Qualities of CEO: CEO vs. Mid-level Managers}

\section{Qualities of an Ideal CEO}

\% CEO minus \% Mid-Level Mgrs.

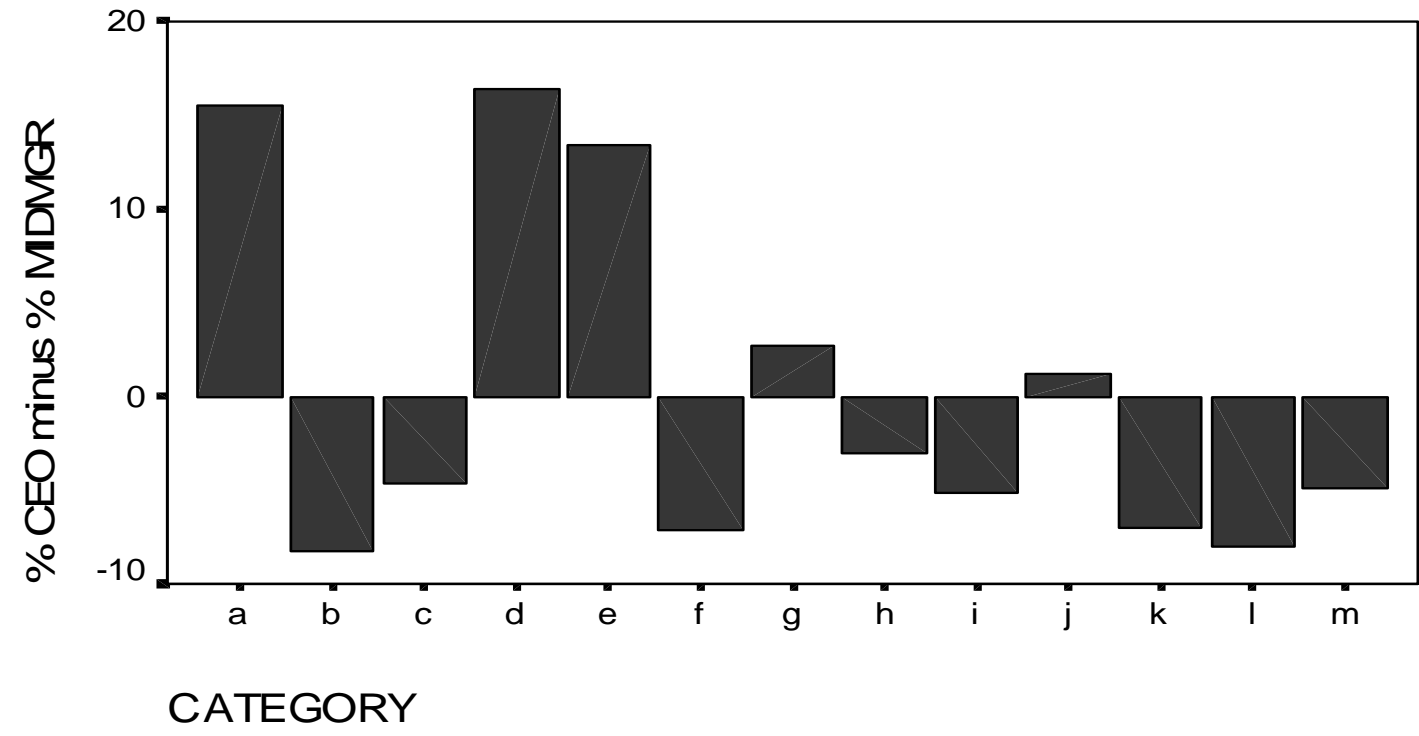

\% CEO's citing item minus \% Mid-Level Mgrs., adjusted to equate means

a) In-depth knowledge of company operations

b) Quick assessment of the situation

c) Quick decision-making

d) Knowledge of finances

e) Knowledge of business legislation

f) Ability to establish contacts outside the company

g) Ability to bear responsibility

h) Ability to predict conflicts

i) Ability to resolve conflicts

j) Willingness to transfer his/her knowledge

k) Team-building skills

1) Ability to assess the performance of subordinates accurately

m) Tact

\section{How Far am I from the Ideal Boss?}

The next step was to see how young managers assess their own strengths and weaknesses, and how they perceive their distance from "the ideal boss." Presumably, as they assume leadership roles, young managers will strive to 
close this perceived gap. We realize, of course, that great caution should be exercized in dealing with any self-reports. Nevertheless, we found interesting results (see Table 2).

Table 2. Assessment of skill deficiencies by "would-be-leaders" (percentage)

\begin{tabular}{|l|c|c|}
\hline Measure & Boss lacks... & I lack... \\
\hline Team-building skills & 42 & 23 \\
\hline Conflict prevention skills & 27 & 29 \\
\hline Knowledge of company's operations & 21 & 26 \\
\hline Abilities to assess the situation quickly & 19 & 21 \\
\hline $\begin{array}{l}\text { Willingness to coach and mentor } \\
\text { subordinates }\end{array}$ & 18 & 20 \\
\hline Ability to establish business contacts & 15 & 38 \\
\hline Conflict resolution skills & 13 & 16 \\
\hline
\end{tabular}

Note: Multiple answers were allowed

Three self-perceived weak points of "future CEOs" in comparison to their present bosses are:

- ability to establish business contacts outside "the factory walls" (38 per cent of managers see their problems here).

- ability to prevent conflicts (29 per cent).

- knowledge of company's operations (26 per cent of managers).

These weaknesses are the logical consequences of limited authority of middle managers, and stem in part from the autocratic close-to-the-vest style of current CEOs, who limit delegation of authority. It is a key aspect of Russian business that finances remain the most cryptic area of company management in Russia, due to the erratic tax system and the permanent threat of racketeering. The secrecy of finances transforms essential business contacts into confidential encounters of company heads. In a sense, the current Russian system almost imposes an autocratic management style. Nonetheless, middle managers view themselves as much more successful team-builders than their bosses. They also believe they surpass their bosses in other "soft" qualities like coaching, conflict prevention and conflict resolution skills. Again, this shows strong similarities 
to American managers, who also tend to stress the key role of human resource management. ${ }^{3}$

Table 3. Ideal and real qualities of middle managers accordingly to CEOs (percentages)

\begin{tabular}{|c|c|c|}
\hline Qualities (skills) & $\begin{array}{l}\text { An ideal middle } \\
\text { manager }\end{array}$ & $\begin{array}{l}\text { Missing qualities of } \\
\text { middle managers }\end{array}$ \\
\hline Professional knowledge & 87 & 38 \\
\hline Willingness to show initiative & 65 & 59 \\
\hline Ability for team working & 59 & 27 \\
\hline Obeying orders & 52 & 32 \\
\hline $\begin{array}{l}\text { Quick assessment of the } \\
\text { situation }\end{array}$ & 50 & 34 \\
\hline Ability to acquire new skills & 45 & 29 \\
\hline Ability to bear responsibility & 41 & 40 \\
\hline $\begin{array}{l}\text { Ability to establish contacts } \\
\text { outside the company }\end{array}$ & 38 & 28 \\
\hline Team-building skills & 27 & 13 \\
\hline $\begin{array}{l}\text { Willingness to mentor } \\
\text { subordinates }\end{array}$ & 12 & 9 \\
\hline Ability to predict conflicts & 10 & 13 \\
\hline Ability to resolve conflicts & 6 & 9 \\
\hline $\begin{array}{l}\text { Willingness to transfer } \\
\text { knowledge to colleagues }\end{array}$ & 6 & 9 \\
\hline Tact & 5 & 7 \\
\hline
\end{tabular}

${ }^{3}$ See: S. Maital (1994), Chapter 10: "Competing by Cooperating”. 


\section{How Do Mid-Level Managers Differ from Ideal Subordinates?}

Having asked future CEOs for their perception of an ideal CEO, it is logical to ask CEOs for their perception of an ideal subordinate (mid-level manager). (see Table 3).

The main qualities of "the ideal middle manager," accordingly to Russian CEOs are:

- Professional knowledge (87 per cent of CEOs stressed that item).

- Willingness to show initiative (65 per cent).

- Ability of team working (59 per cent).

- Obeying orders (52 per cent).

Leadership qualities that middle managers are so proud of like team-building skills or coaching are put by their present bosses at the very bottom of the "list of desired characteristics". Russian CEOs see middle managers as "executives" in the simple meaning of the word - qualified persistent "executors" of somebody other's orders. The leadership component of the work of a middle manager is ignored completely. The revenge comes quickly. CEOs declare "unwillingness to show initiative" and "irresponsibility" as the two prevailing problems of middle managers. In reality, CEOs of Russian companies minimise freedom of action of middle managers and keep them far away from finances. If we recall that CEOs put the "effective performance assessment" at the bottom of their own desired qualities, we are led to the "classical" description of an organization where all initiatives are punished. Logically, in such organisations subordinates are not willing to claim responsibilities for the actions that are out of their control.

The discrepancy between aspirations of "future CEOs" and their treatment by current CEOs goes even further. The negligence of mentoring has here the especially severe consequences. Young Russian managers, after acquiring management training abroad, usually experience a "return shock," facing antiquated production methods and old-fashioned management techniques. This shock leads to exasperation as they realise they have neither resources nor rights to teach colleagues and subordinates modern management techniques. This results in job dissatisfaction, poor work, frustration, discipline problems, and higher personnel turnover. Russia's second transition, from old to new style management, is proving no less difficult than the first transition, from planning to free markets. 


\section{Revealing the Hidden Potential of Young Russian Industrial Managers: Suggestions for Western Partners}

What are the implications of our findings for Western investors seeking to do business in Russia and with Russia? The key question is how can outsiders discover the hidden potential and leadership strengths of young Russian industrial managers, in a system where at present such strengths are given little opportunity to express themselves?

Table 4. The proclaimed devotion of middle managers to their current companies (per cent of managers declaring they will "not to move to another company even for higher salary").

\begin{tabular}{|l|c|c|}
\hline Industry & $\begin{array}{c}\text { Per cent of } \\
\text { managers declared }\end{array}$ & $\begin{array}{c}\text { Total number of } \\
\text { respondents }\end{array}$ \\
\hline Energy production & 45.7 & 81 \\
\hline Transportation & 45.1 & 82 \\
\hline Timber industry & 44.7 & 38 \\
\hline Oil and gas sector & 41.7 & 65 \\
\hline Food-processing & 40.0 & 90 \\
\hline Chemicals & 39.0 & 77 \\
\hline Textile & 38.2 & 68 \\
\hline Catering & 36.4 & 77 \\
\hline Metallurgy (ferrous and non-ferrous) & 33.3 & 27 \\
\hline Electronics & 31.6 & 92 \\
\hline Machine-building & 25.7 & 175 \\
\hline Building materials and construction & 29.3 & 133 \\
\hline Other sectors & 41.2 & 366 \\
\hline
\end{tabular}

The answer depends on the choice of employing such young managers - either by taking them out from their present workplaces or by employing them in their present companies. Those who have tried the first option have had disappointing results, as 'head-hunting' efforts among promising Russian industrial managers 
have not been successful. The reason in part is loyalty. Around 39 per cent of the surveyed young managers declared that they "would not move to another company even for a higher salary." Among top managers, almost 50 per cent said they would reject an offer from another firm. Among middle managers 34.5 per cent said they would stay against a temptation of a higher wage, and the proportion of "devotees" falls to merely 28.5 per cent among shop-floor managers. To explain the fact of high devotion of young Russian industrial managers to their present workplaces we should remind that salary occupies a relatively minor share of the total compensation package. Medical and recreation facilities of Russian industrial firms, and especially options to use subsidised apartments and kindergartens, play a great role in keeping young managers. Hence, the "relocation costs" of the attraction of young managers to a company which provides only monetary remuneration may be quite high.

It is interesting to compare the declared devotion of Russian young managers to their present workplaces across different industries (see Table 4).

The highest loyalty of young managers is observed in such relatively prosperous sectors of the Russian economy as oil, gas, chemicals and electricity production, but also, surprisingly (for outsiders) in timber, chemicals, textiles, transportation and food-processing. The plausible explanation of managers' devotion to their present companies in transportation and food processing is explained by a wide-dispersed practice of "grey" and "black" transactions in those Russian sectors.

Table 5. Attitudes of Russian CEOs and young managers towards possible changes in their companies

\begin{tabular}{|l|c|c|c|c|}
\hline \multirow{2}{*}{ Possible change } & \multicolumn{2}{|c|}{ Oppose (per cent) } & \multicolumn{2}{c|}{ Support (per cent) } \\
\cline { 2 - 5 } & $\begin{array}{c}\text { Young } \\
\text { managers }\end{array}$ & CEOs & $\begin{array}{c}\text { Young } \\
\text { managers }\end{array}$ & CEOs \\
\hline Change of owners & 53.6 & 60.9 & 20,9 & 10.7 \\
\hline $\begin{array}{l}\text { Change of organisational } \\
\text { structures }\end{array}$ & 21.4 & 32.1 & 60,1 & 41.1 \\
\hline
\end{tabular}

The high self-proclaimed devotion of young managers in such crisis-prone sectors as textiles and timber industry just confirm our previous statement about the high share of non-monetary remuneration. Traditionally, timber and textile factories are located in small provincial towns, securing the whole life cycle of their inhabitants - from nurseries to subsidies for funerals. The lowest devotion to the present job is observed in machine-building (only a quarter of managers would not move to another company) and in construction sector (29 
per cent). This data could serve as a reference point for foreign companies planning to recruit personnel for their subsidiaries in Russia.

Western companies probably should choose the second option - to shift leadership to young managers already in the company. They however, should be aware that Russian future CEOs exhibit mixed attitudes towards possible changes in their companies (see Table 5). Like CEOs, they tend to oppose ownership changes - not surprising, given the bleak history of takeovers and mergers in Russia over the past decade.

Only in crisis-prone companies, where managers "have nothing to loose," about half of young managers will welcome the change of owners. However, unlike CEOs, the majority of young managers will eagerly welcome the introduction of new organisational structures in their companies. This makes them ideal candidates for agents of change and renewal within companies.

Our results may hold the key for gaining support of young managers when Western firms do business in Russia. On the one hand, young Russian managers, like managers around the world, desire greater autonomy in decision-making. On the other, Russian CEOs seek to concentrate their power and authority, and demand from middle managers initiative and responsibility, while retaining key authority over financial issues for themselves. Both groups are strongly opposed to changes of ownership. How then can this conflict be resolved?

\section{How can Western firms do business with Russian firms, without being caught in the crossfire of Russia's generational transition in management?}

One possibility is the use of internal ventures as a form of business partnership between Russian and Western companies. Indeed, internal venture projects may embrace various types of activities, from execution of a simple export contract to realisation of a complete investment agreement. ${ }^{4}$ A Western company may negotiate internal ventures with a Russian partner for execution of particular well-defined projects or parts of projects. Moreover, internal ventures as an organisational form to carry out various types of projects provide some unique opportunities for exploiting the potential of young managers.

- Firstly, a Western company may insist on implementation of particular operating rules for such an internal venture, in the same way as Western companies implement with their Russian partners additional measures for quality control. In this way, a "soft" transformation of organisational

${ }^{4}$ Research has shown that in the West joint ventures established for clear well-defined goals, and short stated time periods, are far more successful than more open-ended vaguelydefined joint ventures. This clearly applies to Russia as well. 
structure may take place, enabling young managers to realise their leadership abilities.

- Secondly, the creation of an internal venture does not require transformation of ownership that Russian CEOs oppose. ${ }^{5}$

- Thirdly, under the agreements on joint activities ${ }^{6}$, CEO's of Russian companies retain their control over finances, while allocating more rights to middle managers in less sensitive areas.

- Fourthly, internal ventures may serve as a "testing ground" for promising young managers before giving them positions of overall leadership.

\section{Conclusions}

Our survey of attitudes has revealed the underlying source of conflict in Russia's current generational transition in management. Both CEOs and younger managers believe that sound knowledge of "financial machinery," team-building skills, quick decision-making and ability to establish business contacts are necessary qualities to run a Russian company through the present turbulent times. Young managers feel quite confident in their team-building skills, but acknowledge their weakness in understanding "subtleties" of company operations. At the same time, young managers have little chances to prove their self-declared team-building skills, as Russian CEOs do not value such skills of their subordinates and ignore their functions of coaching and mentoring. Our suggestions for Western partners of Russian firms is to change this situation gradually, by the broader use of the agreements of "simple partnerships" to establish projects with Russian companies and by the broader use of internal ventures for realisation of such projects. Such limited projects can, in addition to generating profits, lead to discovery of new young managerial talent, capable of leading Russia's beleaguered industrial enterprises into the $21^{\text {st }}$ Century.

\section{References}

Czinkota, M. (1997). Russia's Transition to a Market Economy: Learning about Business. Journal of International Marketing, 5 (4), 73-93.

Elenkov, D. S. (1998). Can American Concepts Work in Russia? A Cross-cultural Comparative Study. California Management Journal, 40 (4), 133-156.

\footnotetext{
${ }^{5}$ The current Russian business press is full of stories about middle managers who serve as "black knights" for gaining corporate control on behalf of foreign companies. One of the most effective schemes there is to use a subsidiary to buy back shares in a parent company.

${ }^{6}$ Accordingly to the Civil Code of the Russian Federation, Article 1041, it is possible to join capitals and to realise investment projects not as joint ventures, but by agreements on joint activities (agreements of a "simple partnership") without establishment of a separate legal person.
} 
Fey, C.F. and Denison, D.R. (1998). Organizational Culture and Effectiveness: The Case of Foreign Firms in Russia. Ann Arbor, MI: The William Davidson Institute Working Paper No. 179.

Gurkov, I. (1997). Russian Enterprises' Adaptation to New Economic Realities. Most-Mocm, $7(2), 57-89$

Gurkov, I. (1999). Training Needs in Russian Industrial Companies: Assessment by CEOs. Communist Economies and Economic Transformations, 11, 4, 541-549.

Gurkov, I. (1998). Russian Management under Storm. Ann Arbor, MI: The William Davidson Institute Working Paper No. 68.

Gurkov, I. and Maital, S. (1996). Perceived Control and Performance in Russian Privatized Companies: Western Implications. European Management Journal, 14, 160-166.

Kouzes, J.M. and Posner, B.Z. (1995). The Leadership Challenge. San Francisco: Jossey-Bass

Lawrence, P.R. and Vlachoutsicos, C.A. (1990). Joint Ventures in Russia: Put the Locals in Charge. Harvard Business Review, January-February, 44-54.

Maital, S. (1994) Executive Economics: Ten Tools for Essential Decision-Making. Free Press: New York. (Russian edition: Delo, 1996).

May, R., Young C.B. and Ledgerwood, D. (1998). Lessons from Russian Human Resource Management Experience. European Management Journal, 16, 447-459.

Puffer, S.M. (1994). A Portrait of Russian Business Leaders. The Academy of Management Executive, 8, 41-54.

Shekshnia, S. (1994). Managing People in Russia: Challenges and Opportunities for Foreign Investors. European Management Journal, 12, 298-305.

Shekshnia, S. (1998). Western Multinationals' Human Resource Practices in Russia. European Management Journal, 16, 460-465.

The Economist (2000). Emerging Markets Indicators. October $7^{\text {th }}, 2000,156$. 